\title{
Logika i metafizyka jako nauka podstawowa
}

\section{Friedrich Adolf TRENDELENBURG}

\section{KEYWORDS}

Friedrich Adolf Trendelenburg; Logische Untersucbungen (Logical investigation); logic; metaphysics; philosophy of science; metaphilosophy

\section{ACKNOWLEDGEMENT / ŹRÓDŁO PRZEKŁADU}

Trendelenburg, F. A. (1870). Logik und Metaphysik als grundlegende Wissenschaft (t. 1, s. 4-14). W: F. A. Trendelenburg. Logische Untersuchungen. Leipzig: Hirzel. 
1. Świadomość nauki ogólnej, którą [to naukę] nazywamy filozofią, rodzi się dopiero w opozycji do nauk szczegółowych. W początkach poznania jednym spojrzeniem obejmowało się jeszcze przeciwstawne kierunki. Nauki szczegółowe nie oddzieliły się wówczas od tej nauki ogólnej i dopiero wraz z uszczegółowieniem swych zakresów wystąpiły oddzielnie.

Nauki szczegółowe same prowadzą poza siebie. W swym dążeniu do samowystarczalności starają się one mianowicie odizolować się od siebie jako obszary samodzielne, jednakże muszą wciąż na nowo otwierać swe granice, dostrzegają bowiem, że zawierają ślepe założenia, niedostrzeżone pojęcia podstawowe, przyjęte principia, nierozjaśnione źródła. Gdy z kolei pomiędzy naukami szczegółowymi pojawiają się konflikty, to w sporze tym można odczuć pewną ogólność (ein Allgemeines), której wszystkie nauki muszą być posłuszne. Nauki ujmują idee całości, której same stanowią jedynie część, a mają potrzebę, by myśleć o sobie razem jako o tej całości. Jeśli nauki szczegółowe w kontrolowanych przez siebie zakresach wyznaczają sobie ciasne granice, to wzrok pragnie swobodniejszej perspektywy, której szuka na wyższym poziomie. O ile poszczególne dziedziny, dzięki jednemu stosowanemu rodzajowi badania, wyostrzają umysł, o tyle jednak na skutek konsekwentnej dyscypliny stępiają jego ogólną wrażliwość. W bardziej wyrafinowanym umyśle budzą potrzebę ożywienia, która może wypłynąć tylko z uzupełnienia tego, co szczegółowe, przez to, co ogólne. W tych dwóch koniecznie przeciwstawnych dążeniach ma swe źródło filozofia, którą można nazwać nauką idei (Wissenschaft der Idee), jeśli tylko owa idea odnosić się będzie do myślowego ujęcia całości (Gedanken des Ganzen) określającego części, jak i [do myślowego ujęcia] tego, co ogólne, określającego to, co szczegółowe.

2. Tam, gdzie nie ma jeszcze innych nauk, tam właściwie nie ma również jeszcze żadnej filozofii. To, co na Wschodzie, na przykład w Indiach, pojawia się w takich warunkach jako filozofia, jest właściwie tylko scholastyką religii narodowej, wytworem religijnego ducha, który w wyznaczonym i kontrolowanym przez siebie kręgu myślowym siebie samego ogląda i siebie samego afirmuje, by zaspokoić swój pęd do rozszerzenia i rozpowszechnienia się. Stąd należy wystrzegać się objaśnień filozofii, które grożą pomieszaniem jej z religią lub teologią, przykładowo pojęciowego określenia filozofii jako poznania tego, co wieczne. Należy też wystrzegać się objaśnień, które przypiszą jej tak ogólne ukierunkowanie, że będą pod nie podpadać także nauki szczegółowe, jak na przykład przy określeniu pojęcia filozofii jako dążenia ducha do poznania prawdy. Gdzieżby podziała się godność innych nauk, gdyby im wszystkim nie było wspólne to samo dążenie do tego, co prawdziwe i niezmienne - intencja etyczna (ethische Gesinung).

Historycznie rzecz biorąc, nauki tworzą się $\mathrm{w}$ rozproszonych punktach i zaczynają funkcjonować w odległych miejscach. O tyle też nie pojawiają się jako człony jednej całości, lecz jako niepowiązane fragmenty, z których każdy dla siebie stanowi całość. Mając swe źródło w człowieku, będącym ograniczonym 
elementem postawionym wewnątrz wielkiego świata, zwróconym tylko ku jego częściom, mogą one początkowo dotyczyć jedynie części wszechświata bądź części jego części. Organizm nauk, w którym poszczególne dyscypliny staną się członami jednej całości, przedstawi się w pełnym znaczeniu dopiero wówczas, gdy na nowo zostanie wytworzone uniwersum poznającego ducha. Taka całość, która może dopiero być owocem pełnego poznania, tkwi w odległej perspektywie, niemal w nieskończonym oddaleniu niczym ostateczna idea. W idei tej filozofia i nauki szczegółowe nie byłyby już rozdzielone; filozofia przyjęłaby wszystkie nauki szczegółowe do siebie, a te z kolei by ją podbudowały.

W ten sposób, w ukierunkowaniu na odległy cel, odszukany i przedstawiony zostaje obiekt badań filozoficznych: idea całości w częściach, idea tego, co ogólne, w tym, co szczegółowe.

W każdej nauce znajdują się przede wszystkim dwuaspektowe elementy, które w taki sam sposób przynależą do części, jak i do całości lub ujawniają w szczegółach moc tego, co ogólne. Szczegółowy przedmiot każdej nauki jawi się jako odgatęzienie ogólnego bytu, a swoista metoda ukazuje się jako szczególny kierunek poznającego myślenia w ogóle. To pierwsze odniesienie prowadzi od nauki do metafizyki, drugie zaś od nauki do logiki.

\section{Najpierw to pierwsze.}

Przedmiot każdej nauki jest ograniczony; na jego granicy ukazuje się to, co ograniczające, tj. dziedzina sąsiednia; i w tym sąsiadowaniu obu dziedzin ujawnia się dopiero związek przedmiotów. Gdy jednakże opuszczamy znany nam obraz dziedzin i obszarów nauki, które na sposób geometryczny leżą obok siebie, i zamiast tego obrazu badamy właściwe relacje, to ogólność każdej nauki, która to ogólność jest zdolna objąć to, co szczegółowe, bądź wykształcić w sobie coś wyższego, znajduje się w szczególnym położeniu względem ogólności pozostałych nauk z tego powodu, że coś innego zakłada, jak też sama jest przez coś innego zakładana. W ten sposób rodzi się pytanie, czym jest ów przenikający wszystko ogólny byt? W pytaniu tym tkwi motyw nauki filozoficznej, nazwanej przez Arystotelesa filozofią pierwszą, a przez jego następców, zgodnie z przyjętym porządkiem pism tego filozofa, określonej mianem metafizyki. Zmierza ona do tego, by poznać byt jako byt i to, co bytowi jako takiemu przysługuje. Tymczasem poszczególne nauki biorą pod uwagę tylko fragment bytu, tak jak matematyka, która wykrawa dla siebie wielkość1.

Wszelkie poznanie szczegółowe dokonuje się w jakiejś ogólności, a każda nauka sprowadza swój przedmiot do zasad ogólnych, które wprawdzie w swoisty sposób kształtują się w poszczególnych przedmiotach, ale jednak nie wypływają z tego, co szczegółowe, lecz z doskonalszego źródła. Jeśli byt jako taki zostanie w ten sposób ujęty jako aktywność ogólności w tym, co szczegółowe — niczym

${ }^{1}$ Aristoteles, Metaphys., IV.1. p. 1003 a 21 (przyp. aut.). 
aktywność korzenia w gałęziach - poznanie bytu jako bytu przekształca się w poznanie pierwszych zasad. Pierwszych, gdy wychodzimy od źródła istoty, bądź ostatnich, gdy od zjawiska wznosimy się do istoty z powrotem.

W tym sensie każda nauka znajduje ujście w metafizyce, o ile tylko dotrze tam, gdzie jej zasady szczegółowe przechodzą w ogólne lub raczej gdzie ogólność przekształca się w to, co szczegółowe. To ukształtowanie poszczególnych nauk może być różne, w zależności od przedmiotu zapośredniczone mniej lub bardziej: w ten sposób każda nauka ma swój własny problem metafizyczny, swoją metafizykę. Metafizyka ta musi przedstawić swoisty związek przedmiotu owej nauki z bytem jako takim. Musi przedstawić związek jej zasad z zasadami ogólnymi, które niezależnie od poszczególnych nauk, sytuują się poniekąd przed nimi. Metafizyka matematyki, metafizyka przyrodoznawstwa, metafizyka moralności będą reprezentować różne aspekty bądź różne kierunki jednego badania zorientowanego na ostateczne zasady.

W różnorodnych perspektywach, w jakich różne systemy ukazują pojęcie metafizyki, można rozpoznać stałe znaczenie, zgodnie z którym w przeciwieństwie do wszelkiego bytu jako tego, co szczegółowo rozpatrywane w naukach, niezależnie, czy nauki te mają źródło spekulatywne czy empiryczne, metafizyce przypada w udziale objaśnienie bytu jako bytu, bytu ogólnego, leżącego u podstaw tego, co szczegółowe. Nawet w nowszej filozofii niemieckiej, której nie brakuje oryginalnego ujęcia, to pierwotne pojęcie mieni się jedynie różnymi barwami. Kant określił mianem metafizycznych zasady a priori, bez których nie może istnieć żadne poznanie oparte na doświadczeniu, i napisał w tym duchu metafizyczne podstawy przyrodoznawstwa, metafizyczne podstawy prawodawstwa, metafizykę moralności. Wprawdzie wraz ze swoistym dodatkiem tego, co a priori, zostaje przyjęty pogląd na temat źródeł poznania, który w osobliwy sposób przynależy do ducha pism Kanta, jednakże jako pozostałość metafizyki zostają zachowane ogólność i konieczność, która uzasadnia poznanie tego, co szczegółowe. Gdy Herbart objaśnia metafizykę jako naukę o pojmowalności doświadczenia (Begreiflicbkeit der Erfabrung), to rozumie on doświadczenie jako szczegółowe, natomiast pojmowalność, której zadaniem jest usunięcie sprzeczności z pojęć doświadczeniowych, dokonuje się dzięki ogólności, a mianowicie, według Herbarta, na podstawie pojęcia bytu w sobie. Nim metafizyce nadamy szczególny kierunek, jak to uczynili na swój własny sposób Kant i Herbart, kierunek, który wyznaczałby plan badań, to dobrze jest przemyśleć pojęcie metafizyki w jej źródłowej arystotelesowskiej prostocie.

W ten sposób każda nauka prowadzi do metafizyki, ta zaś stara się ująć byt jako taki, ogólność jako podstawę poszczególnych przedmiotów.

4. Odniesienie drugie - metoda.

Każda nauka zawiera szczególną procedurę, dzięki której umysł (Geist) uświadamia sobie przedmiot nauki, a ostatecznie jego podstawę. Nauki — dzięki 
temu, że starannie eliminują samo mniemanie, które prędkimi prądami przypływa i odpływa i już przy pierwszej próbie poddaje się bez oporu, które nie osiąga rzeczy i mąci tylko umysł - wyznaczają wiele sposobów na obwarowanie przedstawienia i wypełnienie go rzeczowym prawem. Nauki matematyczne, na przykład te, które kształtują swój przedmiot od wewnątrz i poszerzają jego rozumienie, przechodząc od tego, co proste, do tego, co złożone, mają inną procedurę niż nauki przyrodnicze, które swoje przedmioty, będące wytworami zawiłych procesów i skomplikowanych warunków, sprowadzają do prostych elementów i ich relacji. Ze względu na metodologiczną odmienność poszczególnych nauk mówi się często o: logice matematyki, przyrodoznawstwa, prawoznawstwa. Na różne sposoby wyraża się w ten sposób jedność myślenia, która wielorako ukształtowana dopasowuje się zawsze do przedmiotu, aby go ująć. Nauki stanowią dla tej jedności myślenia różnoraki impuls do wynajdywania ciągle nowych sprawności (Künste), którym przedmiot musi się całkowicie poddać. Jednakże wszystkie te nauki przenika jedna sprawność i w nich wszystkich myślenie ujawnia swoistą istotę, zgodną z samą sobą i potężną dzięki niewielu środkom. Myślenie we wszystkim szuka konieczności, nigdy nie toleruje sprzeczności, lecz samo posługuje się sprzecznością, aby okrężną drogą określić konieczność. Jeśli nazwiemy metodą sposób wytwarzania konieczności lub sposób przybliżania się do poznania tego, co konieczne, oraz mierzenia dystansu dzielącego nas od konieczności, to metoda czyni naukę nauką. Wprawdzie metody pojawiają się wraz z przedmiotem nauk, jednakże nie są w nim dane, lecz mają swoją ogólną podstawę w myśleniu opracowującym przedmiot. Powstaje tym samym zadanie polegające na odszukaniu ich źródła w istocie myślenia.

W ten sposób każda nauka, pozostając w relacji do metafizyki, prowadzi ku logice, ku badaniom myślenia wytwarzającego naukę dysponującą poznaniem.

5. Jeżeli nauki chcą się w pełni zrealizować, to potrzebują właśnie tego, na co, wykraczając poza siebie, naprowadzają. Logika i metafizyka są pod tym względem ich własnym postulatem, konsekwencją ich naukowego pędu.

$\mathrm{Na}$ ten sam aspekt wskazują pytania, które wiążą się z rozwojem każdego aktywnego umysłu. Wprawdzie zazwyczaj człowiek dorasta, ucząc się początkowo dzięki otaczającym go rzeczom, nawykły, dzięki przemożnemu wpływowi sposobu myślenia osób dojrzalszych, do bezwiednego utożsamiania wyobrażeń z rzeczami oraz do nieskrępowanej wiary w ich prawdziwość i pewność. Jednakże gdy sam zaczyna zastanawiać się i myśleć, gdy na skutek płonnych nadziei i niepożądanych następstw uczy się nieufności wobec swoich wyobrażeń oraz rzeczy, popada wtedy w zwątpienie. Gdy zaś w zwątpieniu wiemy tylko, że nic nie wiemy, a mimo to odczuwamy pragnienie wiedzy, to stajemy się krytyczni. Pytania dotyczące granic naszego poznania, które powstają w tym nastrojeniu umysłu (Stimmung des Geistes), sięgają bądź do logiki, bądź do metafizyki. Jeśli sprzeczność w nieubłagany sposób rozdziela myśli, które chcielibyśmy ująć 
razem, jeśli czyni spornymi myśli, które chcielibyśmy uznać za zgodne, i niepewnym czyni to, co pewne, to pomimo przemocy sprzeczności można odczuć potęgę myślenia i rzeczowy przymus (Zwang der Sache), który myśleniu nadaje prawa. U podstaw sprzeczności odczuwa się konieczność, która stanowi wspólną zagadkę metafizyki i logiki.

Tam, gdzie sprzeczność zostaje oddalona, nie można mówić jeszcze o pewności. Dopiero świadomość konieczności jest przeciwieństwem wątpienia ciągającego umysł to $\mathrm{w}$ tę, to $\mathrm{w}$ inną stronę. Jeśli wątpienie, które odnośnie do szczegółów jest zbawienne, gdy chce zabezpieczyć pewność wiedzy, poważy się chcieć powszechnie obowiązywać i być ogólną podstawą nauki, to wskutek tego nauka przyjmuje postać wiedzy o niewiedzy. Wątpienie staje się sceptycyzmem, który paraliżuje nerw prowadzącego badania umysłu. Nie wystarczy ogólnie uznać, że taki sceptycyzm sam sobie przeczy, kiedy naucza, że nie można niczego nauczać, a przecież właśnie tego naucza, lub kiedy chce wiedzieć, że niczego się nie wie, a przecież stwierdza, że to właśnie wiemy. Nie wystarczy ogólnie pokazać, że już te negatywne teoria i nauka, pomimo niewielkiego stopnia wiedzy, zakładają stałe punkty, które w konsekwencji zostaną skrycie rozwinięte do postaci wiedzy pozytywnej. Teoretyczne odrzucenie sceptycyzmu tkwi milcząco w logice, która dąży do otwarcia wglądu w istotę konieczności i w istotę procesu, w jakim poznanie samo staje się koniecznym.

6. Jeśli, ogólnie rzecz biorąc, wszystkie nauki razem wskazują w jednym aspekcie na logikę, w drugim na metafizykę jako na poznanie zakładanej przez siebie ogólności, to tym sposobem taki rodzaj poznania, który ujmuje naukę w jej istocie i chce być teorią nauki, będzie musiał objąć jednocześnie metafizykę i logikę. Dopiero na podstawie obu tych odniesień można zrozumieć wewnętrzną możliwość wiedzy i ująć myślenie w jego dążeniu do wiedzy. Naukę, która łączy rozważenie myślenia i bytu jako takiego, można za Platonem nazwać „dialektyką”. Wolimy ją jednak nazwać, aby uniknąć niepotrzebnych konotacji, logiką w szerszym sensie i poświęcimy takiej logice nasze „badania logiczne"2.

By wstępnie ująć jedność logiki i metafizyki, rozważmy tymczasem, co następuje.

Początek każdej nauki tkwi zazwyczaj w czymś pozornie przypadkowym, często w tym, co właśnie zwróci naszą uwagę; jednakże nauka w pełni realizuje się dopiero w tym, co konieczne. Jej rozwój jest ruchem od tego, co przypadkowe, do konieczności, a jej praca to prezentacja związku włączającego przypadkowość w konieczność. Gdy na przykład w naukach empirycznych mamy do czynienia najpierw z oglądaniem rzeczy, następnie obserwacją zjawisk, zbieraniem

\footnotetext{
${ }^{2}$ Trendelenburg nawiązuje tutaj do tytułu całej swojej pracy: Logische Untersuchungen [Badania logiczne] (przyp. tłum.).
} 
tego, co rozproszone, porządkowaniem tego, co zebrane, dostrzeganiem całości $\mathrm{w}$ porządku, to już w obserwacji ujawnia swoje znaczenie to, co niezmienne; w ujęciu całości przebija się zasada (Grund), w zasadzie zaś ujawnia się konieczność. $\mathrm{Na}$ początku umysł sam przez się, nie bez zaciekawienia, doszedł w naukach doświadczalnych do powagi prawa. Prawa, których się poszukuje w doświadczeniu, są wyrazem konieczności, jaka wynika z całości. Całość ta, choć jeszcze ukryta w swej ostatecznej jedności, w nich się jednak ujawnia. Jeśli nauki spekulatywne, jak na przykład czysta matematyka, lubią zaczynać od oderwanej gry myśli, od swobodnej kombinacji elementów, to przecież powaga reguł i praw krępuje tę grę myślową i właśnie w tych naukach po raz pierwszy rozbłyska dla umysłu teoretyczna konieczność. Postępująca w przód nauka przekształca nieokreślone przedstawienia w przedstawienia koniecznie od siebie odgraniczone, a to, co doznane jako rzeczywiste, przekształca ona w to, co z koniecznością pomyślane. Zgodnie z tym konieczność jest celem i miarą wszelkiej nauki i na nią kieruje się metoda będąca dla każdej nauki motywem logicznym; na konieczność nakierowuje też związek z pierwszymi zasadami, stanowiący dla każdej nauki motyw metafizyczny.

Ta konieczność, nigdy nie będąc uprzednio dana, lecz nabyta przez umysł, ukazuje się jako wspólny wytwór tego, co logiczne i metafizyczne. Bowiem myślenie i byt (Sein) są tu oba rozpoznawalne w swych najogólniejszych rysach i w swoisty sposób się ze sobą zrastają.

W konieczności odczuwalna jest przede wszystkim siła myślenia. Bez myślenia nie byłoby ani tego, co możliwe, ani tego, co konieczne, byłoby tylko to, co rzeczywiste. Nie istniałoby to, co możliwe, o ile możliwość pojawiałaby się dopiero tam, gdzie myśl rozluźnia i rozwiązuje swój związek z rzeczywistością i dowolnie operuje odebranymi jej elementami. Nie istniałoby to, co konieczne, o ile konieczność przedstawiałaby byt jako opracowany i przeniknięty przez myśl. Tylko myślenie zdolne jest wypróbować, czy coś nie może być czymś innym niż jest, to znaczy, to, co rzeczywiste, podnieść do rangi konieczności. Jednakże w konieczności w ten sam sposób ujawnia się byt. Bez bytu jako takiego, również nie byłoby tego, co konieczne; bowiem myśl, aby wytworzyć konieczność, musi się w każdym aspekcie dać określić i połączyć z naturą rzeczy (Natur der Sache). Myśl musi rodzić się ku rzeczy (muß zur Sache werden) $)^{3}$ i wychodząc od rzeczy, nakreślić prawo.

Ten podwójny element można wskazać w przykładowy sposób, uwzględniając konieczność każdej nauki. Jeśli zatem pomyślimy wspólnie o obu relacjach, to znaczy relacjach myślenia i bytu, okazuje się, że w konieczności, dzięki której nauka zyskuje rangę nauki, w swoisty sposób byt zostaje przyjęty w myśleniu, a myślenie w bycie.

${ }^{3}$ Formuła „rodzić się ku rzeczy” jest z pewnością nawiązaniem do Platońskiego zwrotu genesis eis ousian. Por. Platon, Fileb 26d (przyp. tłum.). 
Jeśli tak się rzeczy mają, to z tego wstępnego rozważania wynika, że tylko takie poznanie będzie teorią nauki, które $\mathrm{w}$ taki sam sposób, w jaki poszczególne dyscypliny jednoczą w sobie swoje szczegółowe metody i szczegółowe przedmioty, ujmuje też logikę i metafizykę w ich jedności jako podstawę tego, co szczegółowe.

Skoro wszystkie dyscypliny w takiej nauce znajdują swoje oparcie i wznoszą się milcząco na założeniach, do których poznania tylko ona może dążyć, to taka teoria nauki (logika w opisanym, szerokim znaczeniu) jest nauką fundamentalną, philosophia fundamentalis.

Przekład seminaryjny pod kierunkiem i w opracowaniu Wojciecha HANUSZKIEWICZA*

* Dr, adiunkt w Katedrze Filozofii Społecznej Instytutu Filozofii i Socjologii Uniwersytetu Pedagogicznego w Krakowie. E-mail: wojciechhan@wp.pl. 